\title{
ЕСТЕТИКА КЛІПУ У СУЧАСНОМУ СОЩІОКУЛЬТУРНОМУ ПРОСТОРІ
}

У статті в соиіокультурному аспекті розглянуто основні етапи формування кліпу як медіа-форми, вплив його символічних образів і фрагментарної структури на сучасний спосіб мислення та світосприйняття.

Ключові слова: кліп, медіа-, культура, символ, образ, кліпове мислення.

В статье в сочиокультурном аспекте рассмотрены основные этапы формирования клипа как медиа-формы, влияние его символических образов и фрагментарной структуры на современный образ мышиления и мировосприятия.

Ключевые слова: клип, медиа, культура, символ, образ, клиповое мышление.

The article covers in socio-cultural aspect the main stages of the clip as a mediaform, the impact of its symbolic images and fragmented structure on the modern way of thinking and worldview.

Key words: clip, media, culture, symbol, image, clip-art thinking.

Кожна епоха породжує нові лідируючі форми культури, що можуть найбільш ефективно задовольнити інтереси і потреби суспільства, та $\epsilon$ найбільш дієвими 3 точки зору його утилітарних функцій. Сьогоднішня епоха - епоха екранної культури, де нас зусібіч оточують потоки інформації. Людині, яка належить до чинної сьогодні інформаційної цивілізації, потрібно не просто витримати ці потоки, не заплутавшись у них, а й, відсіявши зайве, засвоїти. Останнім часом багато йдеться про кліпкультуру і навіть про кліпове мислення. Щоб докладно розібратися в плюсах та мінусах цієї нової системи, слід, для початку звернутися до самого коріння проблеми, зрозумівши, що ж, власне, $є$ кліп.

Кліп (англ. - обрізати, стригти) - надзвичайно популярний і затребуваний останнім часом вид відеопродукції. Відповідно, відеокліп - нарізка кадрів, досить-таки розрізнених, не об'єднаних якимсь одним змістом, а лише загальною художньою стилістикою. Найчастіше використовується задля реклами продукції музичної, політичної, соціальної, комерційної... Сьогодні кліп пронизує собою практично всі сфери людської діяльності, ми бачимо його в місті на LCD-панелях, в Інтернеті - повсюдно, не лише як музичні ролики або трейлери до кінофільмів, а й як заставки, банери на сторінках Інтернету. Телебачення практично перетворилося на кліпове мовлення, новини подаються блоками, часто не пов'язаними між собою, будь-яка передача перебивається заставкою по кілька разів, а фільм - рекламою. Отже багато речей, які здаються нам звичними і звичайними, насправді давно вже змінилися, набувши форми кліпу.

Слід зауважити, що від самої своєї появи кінематограф тяжів саме до такого стилю викладу і перші фільми мали набагато більше схожості зі знайомими нам музичними кліпами, ніж із художнім кіно, навіть більше ніж мюзикли 60-х років. Перші фільми спеціально синхронізувалися для відтворення під музику, тапер або запрошений оркестр супроводжував своєю грою показ такого фільму. До того ж фільми ці тривали в основному від 30 секунд до хвилини, час, що в майбутньому буде загальновизнаним як ідеальний для засвоєння відеореклами. Особливий внесок у формування кліпу зробив, звісно ж, Жорж Мельєс своїми короткими роликами з використанням так званого «трюку заради трюку». Потім становленню кліпу сприяв Рене Клер зі своїм експериментальним фільмом «Антракт». «Ефект неіснуючого простору» Льва Кулешова, «монтаж атракціонів» Сергія Ейзенштейна, «парад ексцентрика» Григорія 
Козинцева і «монтаж за рухом» Дзиги Вертова, об'єднавшись, створили нову структуру авангардного мистецтва. У цей же період психологія зробила величезний стрибок не лише в розумінні свідомості особистості, а й підсвідомості, а також світу сновидінь. Це розширило уявлення людини не лише про саму себе, а й зіставлення себе 3 дійсністю.

Після приходу звуку в кіно, i, здавалося б, уже усталеного порядку речей, мала місце нова культурна революція, революція 1960-х. Рок-музика, яка викликала такий шквал протесту і зацікавленості, справді змінила світ набагато більше, ніж сама сподівалася, перетворивши не лише музичне звучання, не лише моду, а й моральні цінності, поведінкові підвалини, і свідомість наступних поколінь. Так, завдяки їй, з 60-х років кліп набуває свою вже оглядову форму і неабияку популярність. «Beatles», «The Kinks», Девід Боуї, а пізніше й «The Queen», «Black Sabbath», «Pink Floyd»... всі хотіли не просто досягти успіху в музиці, а й досягти всенародної слави. Також завдяки чималим старанням того самого Енді Ворхола, поняття «зірка» набуло нового характеру, і багато хто зрозумів, що для більшого успіху потрібен не лише синтез мистецтв, а й тиражування, найнадійніший шлях до цього - кінематограф, ще ліпше - телебачення.

Отже доречно, що 1-го січня 1964 року в ефір ВВС була запущена нова програма «Тор of the Pops», яка виходила щотижня і являла собою телеверсію національного хіт-параду, спочатку трансльованого у Великобританії, а потім і в інших країнах світу. Так, зрозумівши переваги нового способу зв'язку з аудиторією, багато виконавців почали знімати на свої пісні спеціальні художні ролики і відправляти їх до телередакції. Водночас деякі заклади стали іменувати себе відеоклубами, найбільш відомий, мабуть, «Max's Kansas City» на Манхеттені, демонстрував концертні відеозаписи в перервах між живими виступами.

Але найзначущіший момент в історії становлення кліп-культури стався 1 серпня 1981 року, коли з ролика «Video Killed the Radio Star» групи «The Buggles» в ефір вийшов абсолютно особливий, не схожий ні на що, до чого звикло телебачення, музичний телеканал MTV.

Телекорпорації не просто лояльно поставилися до такого небаченого досі прибульця, а навіть підтримали його, бо той давав можливість продати набагато більше передплати на кабельне $\mathrm{TV}$, особливо за рахунок сімей з дітьми. Цьому новомодному продукту компанії Viacom, справді першому в історії мистецтва, вдалося звести всю свою реальність до набору символів і мемів. I якщо спочатку MTV позиціонувався як музичний рок-канал, то з часом, більшою мірою завдяки творчості Майкла Джексона, він мутував у поп, не без домішку джазу, соулу, та хіп-хопу.

Особливий інтерес полягає в тому, що дорослі люди практично не розуміли суті того, що відбувалося на екрані, і вже тим більше викликало подив, чому діти і підлітки просто обожнювали цю, здавалося б, відеонісенітницю. Відповідь полягає в особливостях світосприйняття поколінь. Так само, як монтаж фільму «Нетерпимість» вважався занадто радикальним свого часу, кліповий монтаж каналу MTV абсолютно не сприймався старшим поколінням, більш звиклим до послідовного монтажу. Але діти, як відомо, швидше вчаться всьому новому, підлітки обожнюють музику та схильні до всякого роду протестної поведінки, що ідеально поєднується 3 тематикою музичного каналу в стилі рок, котрий тяжіє до певного підпорядкованого хаосу i, звісно ж, моделюється не на порожньому місці.

Як наприклад, Мадонна, що не $є$ оригіналом, а зліплена за моделями минулих поп-кумирів, культурних символів, з якими бажає ототожнюватися. При цьому така нова «зірка» більше не займається своєю окремо взятою галуззю, музикою, як це було раніше, але так само залучена й до відеосвіту. Майкл Джексон, Мадонна, Брітні Спірс, Емінем... хоча всі вони знімалися у фільмах, та все ж таки левова частка їх популярності вибудувана саме на відеокліпі і на безперервній, завдяки йому, зміні образів. Якщо зірці минулого достатньо було знайти і витримати свій неповторний, характерний стиль, чи то холодна елегантність Марлен Дітріх, чи то спокуслива сексуальність Мерілін Монро, то зіркам сучасності цей образ, навпаки, слід постійно змінювати, інакше суспільство просто виробить так званий імунітет. Дуглас Рашкофф увів для позначення подібних явищ вдалий термін - медіа-вірус.

Найяскравіші зірки сучасності залишаються на п'єдесталі слави саме завдяки своїй здатності до мутування. Але дуже обережного, яке не порушує при цьому основну, так би мовити, специфіку продукту. Лише за один рік Мадонна легко може змінити кілька образів, залишаючись собою в кожному з них, а Леді Гага в одному лише трихвилинному ролику перебирає їх від 5 до 15 ти, кардинально різних, але при цьому так само впізнавано екстравагантних. Безперечно, феномен сучасної популярності виконавців не міг би існувати без допомоги кліпу. Завдяки репрезен- 
тації вже знайомого знаку створюється новий, так званий «порожній», який, вийшовши 3-під контролю, вже сам, незалежно, генерує нові лінії сприйняття, спираючись на минулі напрацювання культури та на сучасні реалії.

Згадується захоплення Сергія Ейзенштейна ієрогліфами, от, наприклад, як він пише щодо цього: «Річ у тому, що сукупність $<. . .>$, скажімо краще, поєднання двох ієрогліфів найпростішого ряду розглядається не як сума їх, а як твір, тобто як величина іншого виміру, іншого ступеня; якщо кожен відокремлено відповідає предмету, факту, то зіставлення їх виявляється відповідним поняттю. Поєднанням двох «зображальних» досягається накреслення графічно «незображувального». Наприклад: зображення води і ока означає - «плакати», зображення вуха поруч малюнка дверей - «слухати», собака і рот - «гавкати», рот i дитя - «кричати», рот і птах - «співати», ніж і серце - «сум» і так далі. Та це ж - монтаж!» [7]. А для кліпу монтаж - це справді головне, це його основа. Таким чином, взятий з минулого образ, поєднуючись з іншим, породжує відмінне значення, яке знову може мутувати у світлі останніх фактів, сенсацій, новин, що знову ж перефарбовують передбачуване у нове. Дійсність, як нескінченна репрезентація.

Пет Офдерхайд, медіа-критик і завідувач відділу культури прогресивної газети «In These Times», одним із перших усвідомив, наскільки кардинально відрізняється досвід перегляду відеокліпів від традиційного телебачення: «Однією 3 характерних рис музичного відео як засобу соціального вираження $є$ його відкритість, на меті котрої втягнути глядача в ту комунікацію, яку вона встановлює саме з собою, моделювання паралельного світу, в якому образ $є$ реальністю. Це знищення традиційних кордонів між образом i його реальним референтом, між минулим і сьогоденням, між персонажем і дією, між манірним мистецтвом і стилізованим життям» $[17,159]$.

Канал MTV втілився як дика, не підпорядкована контролю машина мемної інженерії, що, запозичуючи образи з минулого медіа, деформує їх, або ж комбінує, отримуючи таким чином нові. Цей гіперреальний світ симулякрів вільний від диктату як логічних, так і просторово-часових зв'язків. Можна сказати, що саме поява цього каналу, а пізніше і подібних йому клонів, назавжди змінила спосіб світосприйняття наступних поколінь.

Адже світ кліпу повністю ірраціональний. A, за Жаком Лаканом, сенс несвідомого не може бути одним і тим самим як для аналітика, так і для його пацієнта. Позиція режисера кліпу і глядача не обов'язково повинна збігатися. Радше глядач сам збирає власну цілісну картинку із запропонованих роз'єднаних образів. Збирає не лише на основі особистого досвіду, суджень, на основі ландшафту свого внутрішнього світу, можливо, навіть світу своїх сновидінь. Адже людина намагається надати усьому якийсь особливий сенс. Ще Ернст Кассірер, стверджував, що таємниця культурогенезу корениться в формуванні людини, як символічної тварини. А, на думку Лакана, знову ж таки без символічного не існує й уявного. Так, запропоновані режисером образи перетворюються нами в ємкі символи, здатні за лічені секунди передати тонни інформації. Глядач, певною мірою, стає співавтором, а де $\epsilon$ таке безпосереднє залучення, є і прив'язаність. «Якщо це створено мною, воно мені близьке, тому я довіряю йому», ось вона, найвдаліша модель задля впровадження в нетрі нашої підсвідомості, і так вправно, що ми навіть не будемо опиратися тій інформації, а радше захищатимемо іiі.

На підтвердження цих слів варто згадати бодай чи не найбільше відкриття в нейробіології за останні десять років: дзеркальні нейрони - нейрони головного мозку, що моделюють та організовують рухи вищих приматів, вони ж відповідають i за імітацію. Так, завдяки експерименту з шимпанзе, проведеному в 1996 році італійським вченим Джакомо Різолатті, було встановлено, що нейрони однаково збуджуються як при безпосередньому вчиненню дії особисто, так і при спостереженні дій, здійснених іншими. А найцікавіше, що наш мозок здатен моделювати не лише те, що безпосередньо бачить, а й те, що вже моделював колись. Це може слугувати відповіддю на те, як побачена п'ять років тому реклама підштовхне до вибору товару ту людину, котра вже давно й не дивиться телевізор. Вибудувана один раз емоційно заряджена лінія може програватися знов і знов без усвідомлення особистістю.

Та ще задовго до цього приголомшливого наукового відкриття Едмунд Гуссерль, вивчаючи важелі аналогізуючого світосприйняття людини, доходить певних висновків, щодо зіставлення однієї людини з іншою. Ми маємо дивовижний хист приписувати, за аналогією з собою, чомусь відмінному подібні нам риси, залучаючи це відмінне до «нашого» загального світу. Так споживач кліпу неминуче ототожнює себе з героєм відео. Що веде до роз'єднаності і надлому системи, не лише особистісної, а й соціальної, де в загальному хаосі давно перестало бути зрозумілим, що $є$ чим. 
Той саий музичний кліп, що спочатку мав намір представляти виконавця та альбом, з часом перетворився на вдалу платформу для реклами певних брендів, будь-то автомобільні марки, модні дизайнери, напої, клуби, прикраси тощо. Глядач же сприймає побачений антураж не за художній вимисел, а за явну дійсність, тому й кладе своє життя на п’єдестал рекламних вивертів, намагаючись домогтися такої, як на картинці, білизни зубів, шовковистості волосся... Граючи на гіпертрофованому «его» особистості, що піддалась начебто належному зв'язку речей, кліп просто скидає його у прірву невтілених бажань, чим пригнічує людину, а отже робить іiі згодною майже на все, що обіцяє змінити наявний стан речей.

Розірваний світ кліпу намагається втілитися завдяки нашим почуттям, емоціям, котрими він і оперує до повного виснаження та задерев'яніння останніх. Так, насправді, ми не лише опиняємось у розірваному просторі понять, а й поступово втрачаємо зв'язок логічного, цілого. Відокремлюючись, стикаємося 3 «самотністю в натовпі».

Гі Дебор застерігав: «Відчуження глядача і підпорядкування його об'єкту, що споглядається (який $є$ продуктом власної несвідомої діяльності глядача) виражається так: чим більше він споглядає, тим менше він живе; чим з більшою готовністю він впізнає свої власні потреби в тих образах, які пропонує йому панівна система, тим менше він усвідомлює своє власне існування і свої власні бажання» [5].

Так, споживач кліпів зайнятий психотерапевтичною, компенсаторською роботою, роботою над прирученням віртуального, намагаючись оточити себе тими знаками, котрі представлені в кліпі, але так і не досягаючи зростаючого бажаного, по суті постає в амплуа дезорієнтованого істерика, адже, за Жаком Лаканом, істерик - це людина, чий символічний план травматично розбалансований $з$ реальністю.

Можна навіть сказати, що ми вже опинилися замкнутими в суспільстві постійно незадоволених людей, схильних до розладу особистості через неможливість досягнення ідеалу, котрий вічно віддаляється. Адже еgо-ідеал на котрий і повинен спиратися індивід, досить-таки примарний ідеал помилкових цінностей, що сформувався під впливом кліп-культури. I в цьому разі мета ніколи не буде досягнута, тому що неможливо повною мірою імплантуватись у кліповий простір, відповідно над-еgo не буде захищене, не буде підкріплене жодною самопохвалою, усвідомленням власної цінності, таким чином, чіпляючись одна за іншу руйнується вся наявна система особистості. Такий споживач поступово втрачає віру в справжнє «я〉 або й віру у реальність, тобто втрачає істинне уявлення про те, що є реальним взагалі, де закінчується вигаданий образ і починається справжне життя, внаслідок цього легко піддається впливу i нав'язуванню.

Жан Бодрійяр, що поширив поняття симулякру і стверджував про те, що всі ми стали лише копіями копій, так само, вельми вдало, сформулював висновки щодо еволюції реклами і кліп-культури в цілому. На першому етапі вона просто інформувала, потім перейшла до навіювання, яке змінилося «непомітним навіюванням», а нині вона має «управляти споживанням», «надавати йому сенс і цінність» або, іншими словами, формувати стиль та ідеологію споживання.

Лаконічність, яскравість образів, символізм кліпу привчає нас до нового типу світосприйняття. Змінюється навколишній ландшафт, змінюється зовнішній світ людини, безперечно, він тягне за собою зміни і внутрішні, зміни бачення, мислення, взаємодій. Проживаючи в певному «режимі не виявлених смислів», ми звикаємо до відсутності логічного зв'язку, до постійного калейдоскопу явищ. Адже ритм подій настільки прискорений, що іноді з уламків інформації потрібно гранично швидко зібрати свою загальну картинку. Так ми 3 вами спостерігаємо поворотний момент у становленні нової людини в осередку кліпового простору, людини оснащеної віртуальною операційною системою світотворення.

Вісімдесяті-дев'яності роки минулого століття охарактеризувалися вельми значними змінами в устрої та сприйнятті навколишнього світу, певним переходом з індустріальної до інформаційної ери, революційним фактором стало повсюдне використання Інтернету - нової віртуальної реальності, що є по суті кліповою. Незадовго до свого всеосяжного втілення поняття кліпової і віртуальної реальності з'явилося в книгах стилю кіберпанк, який цілком можна назвати літературним нуаром, $з$ єдиною поправкою на постапокаліптичну антиутопію майбутніх часів високих технологій та втрачених моральних цінностей. Паралельно 3 тим, як фантасти Айзек Азімов, Артур Кларк, Руді Рюгер i, звичайно ж, Вільям Гібсон, описували кіберковбоїв (хакерів), які перетинають простори віртуальних світів техногенного майбутнього, такі філософи, як Жан Бодрійяр, Деніел Белл, Зигмунд Бауман, Жан-Франсуа Ліотар, Умберто Еко, переглядали свої погляди, заговоривши про постмодернізм заново, вже в новому посиленому 
світлі. I, до слова, концепції як одних, так і інших досить співзвучні. Але якщо тоді, у вісімдесятих, це був лише один з можливих шляхів подальшого розвитку суспільства, то вже в дев'яностих ці припущення знайшли своє втілення, а в 2000-х стали невідворотною реальністю. Виявилося, що фантастичні світи кіберпанку перейшли у дійсність, а ми, навпаки, частково емігрували до віртуальних світів.

Високотехнічне суспільство третьої хвилі не просто вміщене в інформаційне середовище, але деякою мірою і керує ним, адже здатне брати участь у його формуванні; так найважливішим об'єктом людської діяльності стає обмін інформацією. Його вільна творча особливість багато в чому визначає соціокультурну ситуацію. Таким чином, сьогодні мистецтво дедалі щільніше входить у маси, будь-хто за наявності доступного належного технічного оснащення здатен створити власний кліп. Тобто рівень креативності в цілому підвищився, це навіть стало модним, i бодай чи не кожен прагне відкрити в собі художника. Але в більшості своїй сьогоднішнє розуміння творчості змінилося, ставши схожим на збирання пазла. Ми заміщуємо поняття творчості поняттям креативності. Ми чимдалі менше мислимо світ, чимдалі більше уявляємо його, використовуючи готові символи, готові форми.

Вслід прогресом айфонів та андроїдів, які дають змогу дивитися відео по дорозі на роботу, фотографувати, водночас прослуховуючи музику, та читати новини, спілкуючись із друзями, ми просто не можемо не помітити, як спосіб мислення 3 понятійного змінюється на кліповий, і розуміємо, що це має спричинити глобальні зміни також і в соціокультурному середовищі. Якщо сприймати сучасне мистецтво, як дзеркало (давно вже облишивши свою елітарність і надавши перевагу масовості), що відображає сьогоднішні реалії, то зможемо роздивитися в ньому і те, якою насправді стала наша цивілізація. Ми зможемо побачити в кліпах себе ідеалізованими, такими, якими хотіли б бути. Якщо звернутися до давньогрецьких скульптур, то ми також помічаємо їх піднесену досконалість, очевидне перевершення над нами повсякденними. Адже мистецтво покликане не лише відображати цінності епохи, а й служити їм величним орієнтиром. I, звісно ж, сучасне комп'ютеризоване мистецтво не менш, ніж «мистецтво минулого», здатне допомогти нам пізнати себе.

Кліпи мають неповторну особливість - здатність обходити логічне судження розуму і потрапляти безпосередньо у підсвідомість. Ми немов дивимося не відеопродукт, а якийсь забутий сон, в котрому події абсолютно не зобов'язані мати причину або бути виправданими. І в кліпі, як уві сні, головне не те, що відбувається, а те, які відчуття це нам залишає. Весь інтерес в тому, що мозок в цілому не здатний відрізняти реальність навіть від галюцинації... він засвоює лише те, що передають йому органи чуття. А вся особливість кліп-культури побудована саме на тому, щоб стимулювати людські відчуття та емоції. Тоді як пряма ілюстрація $є$ недоцільною, а часом і недоречною.

У кліпі зображення, як правило, стоїть окремо від музичної асоціації думок і являє собою особливий символічний ресурс, за допомогою котрого режисери прагнуть передати не зміст пісні, а іiі атмосферу, витримавши при цьому певний заданий візуальний стиль, і така тенденція спостерігається майже в будь-якому рекламному ролику. Можна сказати, що основне завдання режисера кліпу полягає в тому, аби певний настрій було точно передано у візуальній формі. Та головним стає не те, що відбувається, а те, яке це справляє на нас враження, яке дарує відчуття, в який занурює стан i на що врешті наштовхує. Таким чином використовуючи, образ-емоцію, кліп оперує й іншими, вдало відокремленими Дельозом: образом-перцепцією (те, що відчуваємо), образом-концепцією (як ми реагуємо), образом-імпульсом (що викликає жагу), образом-дією (що змушує поводитися певним чином), образом-рефлексією (що спонукає до трансформації) та навіть образом-ставленням (що навішує або знімає з нас певні ярлики). Отож кліп живе не стільки світом зовнішнім, як це поширено в кінематографі, а переважно внутрішнім світом, світом сновидінь, таємних бажань і фобій, чимсь прихованим від сторонніх очей, зануреним у нетрі. Андре Бретон вбачав можливість вільних асоціацій, сновидінь у кіно, проте не фільм, а саме кліп, повною мірою зміг втілити «той самий» світ несвідомого.

Цікаво, що у австралійських аборигенів є таке сакральне поняття, як «час сновидінь» - термін, що вживається задля позначення особливої міфології корінного населення континенту, в уявленні котрого наш світ - $€$ сон, що колективно споглядається. А дослідники з Інституту психіатрії Товариства імені Макса Планка в Мюнхені, вивчивши в свою чергу активність мозку сплячих людей, дійшли висновку, що сон сприймається нами за абсолютну реальність i, коли нам щось сниться, у мозку проявляється та ж сама активність, якби події сну відбувалися наяву. Ми відзначаємо це за тим, аби особливим чином наголосити - світ кліпу 
насправді найближчий до світу сновидінь і сприймається подібним чином. Відповідно, вивчаючи одне поняття, ми повинні звернутися і до іншого. Згадавши хоча б Зигмунда Фрейда, який зауважував, що всі психічні процеси людини підкоряються принципу задоволення, а сни покликані зняти наше психічне напруження, а також дають змогу задовольнити наші потаємні бажання. Хоч як дивно, але те ж саме можна сказати і про світ кліпів. Люди, які потрапили під цю особливу культуру, не просто занурюються в стан мрій, коли можна не думати, а відразу сприймати, а й залежать від нього, як способу втечі від реальності.

В той же час наука онейрологія вважає, що сновидіння безпосередньо пов'язані 3 фазою швидкого руху очей (очних яблук), що характеризуються особливим підвищенням активності головного мозку, тоді як м'язи тіла, навпаки, дуже розслаблюються. Саме при цій фазі ми бачимо найяскравіші сни, які й найкраще запам'ятовуємо. Такі відкриття вдало беруть до уваги провідні медіа-фахівці світу.

Популярні останні роки в медіа-системі технології айтрекінгу, відомі й під назвою окулографія, відстежуючи і записуючи переміщення погляду при спостереженні рухомого об'єкта на екрані, дають можливість робити висновки щодо того, які саме точки (зони) цікавлять людину. В цілому ж, цей рух очей не лише відображає розумові процеси індивіда, а й також може і формувати їх. Вимірювання траєкторії руху погляду і точок фіксації погляду, разом з вимірюванням розумової активності швидко висвітлює ті зони затребуваності, в які й варто помістити найцінніші об'єкти повідомлення, що надсилається. Важливо те, що точка ця, частіше за все, не осмислена, а є скоріш подразником і може бути просто мерехтливою крапкою на екрані. Згадаймо, що першим ще Маршалл Маклюєн звернув увагу на роль засобів масової комунікації, особливо телебачення, у формуванні свідомості незалежно від змісту повідомлення. Звідси ж випливає розуміння популярності графічних кліпів, геть позбавлених сюжету, але які являють собою переплетіння ліній, кіл тощо. Медіа-художник, немов шаман індіанських племен, заново розкриває міфологію тотемних образів і за допомогою ритмів, повторювання емблементарних відеосемплів, вводить нас у гіпнотичний транс. Це нагадує нам ту психологію абстрактних форм, ту чуттєвість, котру намагалося втілити так зване «сугестивне кіно». У якому ритміко-музичні шукання Жермена Дюлака підштовхнули нас до світу сновидчих асоціацій і через певну емоцій- ність, поезію «чистого кіно» підготували до приходу сюрреалістів, які навчили грати з візуальними складовими реальності, змінюючи їх сенс.

У свою чергу футуролог Джеймс Мартін, що також був одним $з$ провісників Інтернету, розділив людей на два типи: «люди книги» і «люди екрана». Перші пристосовані до більш плавного, послідовного мислення, другі ж, до кліпового, асоціативного. Якщо перші відрізняються особливою уважністю, аналітичністю, то другі реагують гранично швидко і потребують споживання нової інформації дедалі більше й більше, потрапляючи таким чином у залежність. Такі люди краще навчаються за фільмами і картинками, ніж за книгами і схемами, але їх так званий «швидкий відгук» значною мірою заважає координації 3 іншими. Так, особливо на Заході, ми можемо спостерігати ціле покоління дітей, котрі ще не вміють говорити й писати, але чудово володіють високими технологіями, і вже проглянули більше відеообразів, ніж людина ще якихось років 20-30 тому могла побачити за все своє життя.

I, за словами того ж Джеймса Мартіна, людина в недалекому майбутньому з Homosapiens перетвориться на Homofuturies, але в порівнянні $з$ сучасною «людині майбутнього», неминуче доведеться пережити якесь помутніння розуму» [12]. Всьому виною високі технології, прискорена і стиснута подача інформації в динамічній, а часом і агресивній формі. Сучасна людина споживає масу подекуди протилежної інформації та емоцій, але не спроможна в такій кількості їх «перетравити» та засвоїти, здатність до навчання, таким чином, падає. Сучасна дитина, що виросла на цій нескінченній зміні кадрів, чий мозок просто перевантажений візуальною інформацією, від якої були захищені попередні покоління, використовує новий спосіб мислення, кліповий, тобто фрагментарний, покликаний захистити свідомість від такого натиску, вибравши лише найцінніші, за розсудом об'єкта, меседжі.

I це лише друге, третє покоління, що виросло на телепереглядах і насамперед із пелюшок увібрало Інтернет-технології. Але вже зараз рентгенівські знімки мозку дітей показують разючу відмінність від мозку їх батьків. У двадцятирічних візуальна пам'ять в півтора-два рази краща ніж у тридцятирічних людей. Разом з тим європейські лектори просто б'ють на сполох, заявляючи про те, що сучасні студенти просто нездатні засвоїти лекцію, якщо вона не оснащена відеорядом i яскравими презентаціями. Діти, що виросли в епоху високих технологій, по-іншому дивляться 
на світ. «Їх сприйняття - не послідовне і не текстове. Вони бачать картинку в цілому і сприймають інформацію за принципом кліпу» [16], - говорить професор, доктор психологічних наук, Рада Грановська. Виходить так, що ми дедалі більше і більше моніторимо, збираємо дані, але при цьому дедалі старанніше забуваємо про наявність програми, що ці самі дані обробляє. Інформація, яка надходить, не затримується надовго, змінюючись новою. Увага моментально з одного об'єкта перестрибує на інший. Ми освоюємо спосіб моментальної реакції, оснований на інтуїції, а не на аналізі, що, крім часу, передбачає й послідовність міркувань, де мало б місце осягнення усіх даних. Сьогодні подібна схема безглузда, адже не ефективна. Таким чином, закінчується час «великих наративів», дізнаймося про ціле за його уламками.

Безперечно, глобальний зв'язок між високими технологіями і змінами в мисленні і свідомості в цілому очевидний. 3 кожним роком люди стають дедалі більш візуально-орієнтованими, тому без кліпового мислення їм просто не витримати стресовий потік наростаючого інформаційного сміття. Новий час диктує свої закони, і його відмінні риси вельми очевидні, оскільки в тому і іншому способі мислення задіяні зовсім різні зони мозку. Так попереднє покоління - люди 3 понятійним мисленням, краще засвоюють інформацію, але повільніше обробляють iĭ, і результат отриманий після такого аналізу вже може бути не актуальним. Кліповики ж сприймають все швидко і реагують так само гранично швидко. Але також швидко забувають, різко переключаються на інші інтереси, емоції і потребують їх постійного поповнення. До того ж кліпове мислення багато в чому є стереотипним. 3 вихоплених за частки секунд кадрів потрібно не лише вловити сенс, а й сформувати судження. I мимоволі постає питання, чи завжди правильними будуть такі судження.

Важливо якнайшвидше зрозуміти специфіку кліпу, усвідомити те, що його неконтрольовані образи, міфи і символи дуже легко надходять до нашої підсвідомості і мають беззаперечний вплив. Можливо, найцінніше, що ми можемо створити це гармонію. В тому числі гармонію між минулим i сьогоденням, яку ми можемо встановити, навчившись повною мірою використовувати обидві півкулі мозку, обидва способи мислення.

Ми вважаємо, що 3 пришвидшеним перемиканням уваги кліпового мислення можна боротися за допомогою книги, вдумливо читаючи хоча б по кілька абзаців класичної літератури, поступово збільшуючи обсяг прочитаного. За допомо- гою тренування пам'яті, де згодиться заучування віршів. Йога стане в пригоді у самовдосконаленні, пропонуючи численні техніки з концентрації уваги. Переказування історій, написання сюжетних текстів, прикладна творчість, звісно ж, допоможуть. А іноді слід влаштовувати й розвантажувальні дні, повністю ізолювавши себе від зовнішньої штучної інформації, особливо візуальної, це стосується не лише міського ландшафту з усіма його бігбордами, а й барвистих етикеток, мобільних телефонів тощо. Подеколи ми забуваємо, яким дорогоцінним та збагачувальним може бути просте спілкування з реальними, схожими на нас людьми.

Отже, як завжди, починати слід із себе. I якщо трохи змістити свої власні пріоритети, хоча б із матеріальних на інтелектуальні, то кліп, так само зможе бути неоціненним інструментом освіти. Адже коли ще за допомогою калейдоскопу кадрів, упродовж усього якихось трьох хвилин, можна було скласти уявлення про атмосферу, звичаї, культуру цілої країни завдяки короткій формі презентаційного кліпу.

Кліп не лише впливає на всі верстви суспільства, поміж яких поширюється, а й відображає різні цінності цього суспільства, його соціальну структуру і культуру. Сьогодні кліп, як еталонний продукт постіндустріального суспільства, здебільшого паразитує на соціальному організмі смислів і образів, використовуючи їх переважно для власної потреби. Подолання такої тенденції ось основне завдання філософа. Адже кліп працює 3 масовою культурою так, як ще не вдалося жодному фільму, ані серіалу, ні комп'ютерній грі, тим більше книжці, яким, попри всі зусилля, так i не вдалося настільки глибоко зануритися у свідомість мас.

\section{Джерела та література:}

1. Бодрийяр Ж. Симулякры и симуляция / Жан Бодрийяр ; пер. 3 фр. О. А. Печенкина. - Тула : Тульский Полиграфист, 2013. - 204 с.

2. Бодрийяр Ж. Система вещей / Жан Бодрийяр ; пер. с фр. и сопроводительная статья С. Зенкина. - М. : Рудомино, 2001. $-218 \mathrm{c}$.

3. Гуссерль Эд. Собрание сочинений. Т. І. Феноменология внутреннего сознания времени / Эдмунд Гуссерльд ; пер. с нем. В. И. Молчанова. - М. : Гнозис, 1994. - 162 с.

4. Гуссерль Эд. Собрание сочинений. Т. III (1). Логические исследования. Т. ІІ (1). Исследования по феноменологии и теории познания / Эдмунд Гуссерль ; пер. с нем. В. И. Молчанова. - М. : Гнозис, Дом интеллектуальной книги, 2001. $-576 \mathrm{c.}$.

5. Ги Эрнест Дебор. Общество Спектакля [Электронный pecypc]. - Режим доступа: https://avtonom.org/old/lib/ theory/debord/society_of_spectacle.html. - Назв. с экрана. 
6. Дери М. Скорость убегания: киберкультура на рубеже веков / Марк Дери ; пер. с англ. Т. Парфенова. - Екб. У-Фактория, 2008. - 480 с.

7. Сергей Эйзенштейн. За Кадром [Электронный ресурс]. Режим доступа: http://www.metaphor.narod.ru/eizenstein beyond.htm. - Назв. с экрана.

8. Кассирер Э. Избранное. Опыт о человеке: введение в философию человеческой культуры / Эрнст Кассирер ; пер. А. Муравьева. - М. : Гардарики, 1998. - 784 с.

9. Кастельс М. Информационная эпоха: экономика, общество и культура / Мануэль Кастельс ; пер. с англ. ; [под науч. ред. О. И. Шкаратана]. - М. : ГУ ВШЭ, 2000. -608 с.

10. Кириллова Н. Б. Медиа-культура: от модерна к постмодерну / Наталья Кириллова. - М. : Академический Проект, 2005. - 448 c.

11. Лакан Ж. Семинары. Книга 11. Четыре основные понятия психоанализа / Жак Лакан ; пер. с фр. А. Черноглазова. М. : Логос, 2004. - 304 c.

12. Человек будущего - мнение футуролога [Электронный pecypc]. - Режим доступа: http://fant-usas.at.ua/publ/ chelovek_budushhego_mnenie_futurologa/1-1-0-242. Назв. с экрана.

13. Маклюэн М. Понимание Медиа: Внешние расширения человека / Маршалл Маклюэн ; пер. с англ. В. Г. Николаева. - М. : Гиперборея, Кучково поле, 2007. - 464 с.

14. Маньковская Н. Б. Эстетика постомодернизма / Н. Б. Маньковская. - СПб. : Алетейя, 2000. - 347 с.

15. Медіа-культура особистості: соціально-психологічний підхід: навч.-метод. посібник / за ред. Л. А. Найдивої, О. Т. Баршипольця. - К. : Міленіум, 2009. - 440 с.

16. Рада Грановская. Люди с клиповым мышление элитой не станут [Электронный ресурс]. - Режим доступа: http:// doctor.kz/health/news/2015/04/07/17216. - Назв. с экрана.

17. Рашкофф Д. Медиавирус. Как поп-культура тайно воздействует на ваше сознание / Дуглас Рашкофф ; пер. с англ. Д. Борисов. - М. : Ультра Культура, 2003. $358 \mathrm{c}$.

18. Садуль Ж. История киноискусства от его зарождения до наших дней / Жорж Садуль ; пер. с 4-го фр. издания М. К. Левиной - М. : Инлитиздат, 1957. -313 с.

19. Уорхол Э., Хекетт П. ПОПизм: Уорхоловские 60-е / Энди Уорхол, Пет Хекетт ; пер. 3 англ. Л. А. Речная. - СПб. : Амфора, 2012. - $350 \mathrm{c}$.

20. Ямпольский М. Из истории французской киномысли : Немое кино 1911-1933 гг. / Михаил Ямпольский ; пер. с фр. [предисл. С. Юткевича]. - М. : Искусство, 1988. $317 \mathrm{c}$.

\section{References}

1. Baudrillard, J. (2013). Simulacra and Simulation. (O. Pechenkina, Trans). - Tula : Tulskiy Poligrafist, 204 [in Russian].
2. Baudrillard, J. (2001). The System of Objects. (S. Zenkina, Trans). - Moscow : Rudomino, 218 [in Russian].

3. Husserl, Ed. (1994). Vol. I. On the Phenomenology of the Consciousness of Internal Time. (V. Molchanova, Trans). Moscow : Gnozis, 162 [in Russian].

4. Husserl, Ed. (2001). Collected works. Vol. III (1). Logical Investigations. Vol. II (1). Studies on phenomenology and theory of knowledge. (V. Molchanova, Trans). - Moscow : Gnozis, Dom intellektualnoy knigi, 576 [in Russian].

5. Guy-Ernest Debord. The Society of the Spectacle. - https:// avtonom.org/old/lib/theory/debord/society_of_spectacle. htm.

6. Dery, M. (2008). Escape Velocity: Cyberculture at the End of the Century. (T. Parfenova, Trans). - Ekb : U-Faktoriya, 480 [in Russian].

7. Sergei Eisenstein. Behind frame. - URL: http://www. metaphor.narod.ru/eizenstein_beyond.htm

8. Cassirer, E. (1998). Favorites. Experience of man: an introduction to the philosophy of human culture. (A. Muravev, Trans). - Moscow : Gardariki, 784 [in Russian].

9. Castells, M. (2000). The Information Age: Economy, Society and Culture. (O. Shkaratan, Trans). - Moscow : GU VshE, 608 [in Russian].

10. Kirillova, N. (2005). Media-culture: from the modern to the postmodern. - Moscow : Academic Project, 448 [in Russian].

11. Lacan, J. (2004). Seminars. Book 11. The Four Fundamental Concepts of Psychoanalysis. (A. Chernoglazova, Trans). Moscow : Logos, 304 [in Russian].

12. Emelyanenko, V. (2013). The man of the future - opinion of the futurologist. - URL: http://fant-usas.at.ua/publ/chelovek budushhego_mnenie_futurologa/1-1-0-242.

13. McLuhan, $\overline{\text { M. (2007). Understanding Media: The Extensions }}$ of Man. (V. Nikolaeva, Trans). - Moscow: Giperboreya, 464 [in Russian].

14. Mankovskaya, N. (2000). Aesthetics of Postmodernism. - St. Petersburg : Alateyia, 347 [in Russian].

15. Naydiva, L. \& Barshpilts, O. (Eds.). (2009). Media culture of the person: socio-psychological approach. - Kiev : Millennium, 440 [in Ukrainian].

16. Granovskaya Rada. (2015). People with clip-like thinking will not become elite. - URL: http://doctor.kz/health/ news/2015/04/07/17216.

17. Rushkoff, D. (2003). Media Virus: Hidden Agendas in Popular Culture. (D. Borisov, Trans). - Moscow: Ultra Culture, 358 [in Russian].

18. Sadoul, G. (1957) The history of cinema from its inception to our days. (M. Levin, Trans). - M. : Inlitizdat, 313 [in Russian].

19. Warhol, A. \& Hackett. P. (2012). POPism: The Warhol Sixties. (L. Rechnaya, Trans). - Saint Petersburg: Amphora, 350 [in Russian].

20. Yampolskiy, M. (Eds.) (1988). From the history of the French motion picture: Silent cinema 1911-1933. (S. Yutkevich, Trans). - Moscow: Iskusstvo, 317 [in Russian]. 